Hoog van de Toren

\title{
Edgar Pelupessy
}

\section{Herwaardering voor de kunsten}

\author{
Een pleidooi tegen het rendementsdenken
}

Op maandag 31 augustus vond de opening van het academisch jaar plaats in het Academiegebouw van de Rijksuniversiteit Groningen. Normaliter wordt deze gelegenheid uitbundig gevierd met een optocht van verschillende academici en studenten, marcherend richting de Martinikerk, om daar eenmaal aangekomen, het academisch jaar op ceremoniële wijze te openen. Maar dit jaar was daar geen sprake van. De huidige pandemie gooide roet in het eten waardoor de locatie en ceremonie moesten worden veranderd. Deze ietwat sombere opening van het academisch jaar werd nog eens verder benadrukt door de spreker van dat jaar, Minister van Buitenlandse Handel en Ontwikkelingssamenwerking, Sigrid Kaag (D66). Haar toespraak was op zijn allerminst rooskleurig. COVID-19 heeft het onderwijs in Nederland er niet veel makkelijker op gemaakt. Complete lesmodules moesten worden gedigitaliseerd of zijn nog midden in het proces van digitalisering, hetgeen allemaal voor extra spanning en stress heeft gezorgd onder velen binnen het onderwijs. Deze extra stress komt nog eens bovenop het feit dat het huidige onderwijs in Nederland al jaren te kampen heeft met een overmaat aan stress en spanning door een gedachtegoed dat zich heeft weten door te dringen tot de fundamenten van de Nederlandse maatschappij: het rendementsdenken.

Het rendementsdenken is een manier van denken waarbij het voornamelijk draait om efficiëntie en winst. Vanaf de jaren 80 waaide dit gedachtegoed vanuit de Verenigde Staten en het Verenigd Koninkrijk over en begon het zijn intrede te doen binnen de Nederlandse politiek. Het rendementsdenken speelde een grote rol in het opkomende neoliberalisme van die tijd. Belangrijk aanstichter van deze ontwikkeling in Nederland was de toenmalig Minister van Financiën Onno Ruding (CDA). Afkomstig uit de bankwereld kreeg hij de taak van premier Ruud Lubbers om Nederland er weer financieel bovenop te krijgen. Onder zijn bewind werden forse bezuinigingen doorgevoerd en werd er het zogenaamde no-nonsense beleid geïmplementeerd. Het begrotingstekort moest worden teruggebracht 
door de overheidsuitgaven te beperken. Kosten voor sociale zekerheid werden daarom verlaagd waardoor er lagere, en vooral minder, uitkeringen werden verleend. Deregulering, privatisering en liberalisering waren de sleutelwoorden van Lubbers' en Ruding's beleid. In andere woorden: laat de vrije markt maar zijn werk doen. ${ }^{1}$ Burgers werden steeds meer als consumenten beschouwd waardoor een bepaalde distantie ontstond tussen de overheid en haar burgers. Hiermee begon een gedachtenverandering die de Nederlandse maatschappij tot de dag vandaag beïnvloedt.

$\mathrm{Nu}$ een kleine veertig jaar later zit dezelfde gedachte nog steeds vastgeroest in de Nederlandse politiek. Zo wist Sigrid Kaag het verder in haar openingstoespraak van het academisch jaar nog eens mooi te verwoorden, en ik parafraseer hier, door te stellen dat de wetenschappen niet tegen elkaar uitgespeeld moeten worden. Ze doelde hiermee op het feit dat er mede door het rendementsdenken een ontwikkeling binnen het Nederlandse onderwijs is ontstaan dat alleen maar uit is op het verdienmodel. Een belangrijk gevolg van deze ontwikkeling is dat geesteswetenschappen het vervolgens moeten ontgelden ten opzichte van andere wetenschappen omdat zij niet voldoen aan dit verdienmodel, tenminste niet op korte termijn. ${ }^{2}$ Dit soort dwazenpolitiek moet drastisch veranderen willen wij als maatschappij de waardering voor onze wetenschap weer in balans krijgen.

Deze verandering moet al beginnen in de jongere jaren van ons leven. Stelt u zich eens voor dat aan een peuter wordt gevraagd wat hij of zij later wil worden. Meestal krijg je toonaangevende beroepen, zoals brandweerman, dokter of politieagent als antwoord terug. Het kleine kind baseert zijn antwoord natuurlijk op zijn relatief kleine referentiekader. Wanneer dezelfde vraag wordt gesteld aan een middelbare scholier die zijn profiel moet kiezen, is het antwoord moeilijk in te schatten. In dit geval heeft het kind een dusdanig referentiekader opgebouwd waardoor er uit een oneindig aantal beroepen valt te kiezen. Voor mijzelf was deze keuze ook erg lastig. Ik maakte de fout het verkeerde profiel te kiezen waardoor ik een jaar lang ongelukkig vakken als biologie en scheikunde moest volgen. Ik had dit vakkenpakket gekozen omdat mij was verteld dat het de grootste kans op een baan zou geven later. Gelukkig was er voor mij een goede mentor die mijn ongelukkigheid opmerkte, en mij adviseerde een ander profiel te kiezen. Een profiel dat meer aansloot op mijn belevingswereld en interesses, waardoor ik weer een beter gevoel kreeg over school en leren. Helaas is dit voor heel veel andere leerlingen niet het geval. 
In onze huidige cultuur worden kinderen namelijk van jongs af aan al geconfronteerd met de gedachtekronkel van het rendementsdenken. Ouders forceren hun kinderen te streven naar een carrière puur en alleen gebaseerd op geld. Verhalen van ouders die zich tegen het Cito-advies van de basisschoolleraar keren zijn tegenwoordig geen uitzondering meer, terwijl dit vroeger vrijwel ondenkbaar geweest zou zijn. Deze ontwikkeling heeft alles te maken met het rendementsdenken. 'Kinderen zijn de toekomst' is het devies dat het beste past bij deze denkwijze. Vakken als muziek, drama, Latijn, en geschiedenis worden als nutteloos beschouwd omdat zij geen praktisch doel zouden hebben. Zij brengen volgens het rendementsdenken geen geld in het laatje en zouden daarom vanaf jongs af aan moeten worden gemeden. Het is niet zo gek dat het huidige kabinet overtuigd is van dit denksysteem aangezien zij als een voortvloeisel kunnen worden beschouwd van een politieke stroming waarin de staat wordt gerund als een grootbedrijf en dus streeft naar maximale efficiëntie.

Toen ik eenmaal van profiel veranderde viel er een last van mijn schouders. Ik kreeg weer plezier in het leren. Met vakken als drama en geschiedenis kon ik mij een wereld inbeelden die niet meer bestond - en dat heeft nut. Toch bleef ik twijfelen aan mijn keuze aangezien ik telkens met mijn neus op de feiten werd gedrukt. Zo werd ik tijdens verjaardagen of andere sociale gelegenheden meerdere malen bestookt met de existentiële vraag wat ik in vredesnaam wilde bereiken met zo'n pretpakket. 'Wat voor werk viel ermee te krijgen?' 'Als men de cijfers bekijkt heb je meer aan scheikunde en natuurkunde.' 'Ja, het profiel cultuur en maatschappij doe je voor de lol omdat je daar geen brood mee op de plank brengt.' Er tegenin gaan had geen zin aangezien mijn familieleden dus met onderbouwde cijfers kwamen aanzetten waardoor ik met een mond vol tanden stond. Deze waanzin dient een halt toe te worden geroepen, omdat het leidt tot een vergiftigde samenleving. Een samenleving waarin mensen met een alfa- achtergrond zich constant moeten verdedigen tegen de ander die het nut er niet van inziet.

Dat een vak als kunst of Latijn nut heeft, was voor mij als zestienjarige puber erg lastig onder woorden te brengen. Daarbij moet worden gezegd dat de afweging of iets nut heeft of niet voor een puber wel vaker lastig is. Maar met zes jaar ervaring in het voeren van discussies met familieleden en drie academische jaren verder, ben ik eindelijk in staat mijzelf te verdedigen tegen dit soort geklets. Alfastudies en kunst hebben nut omdat zij in staat zijn de algemene werkelijkheid te verwerken en verzachten. Concrete voorbeelden 
hiervan zijn beeldende kunst, letterkunde, geschiedenis, muziek en films. In deze context zijn ze de paria's van elk verjaardagsfeestje maar dienen een uitermate belangrijk doel. Ze kunnen namelijk worden beschouwd als de geestelijke instrumenten waarmee de mens in staat is tot het verwerken van zowel fysieke als mentale gebeurtenissen. De algemene werkelijkheid is niet gebaseerd op winst en efficiëntie maar op onvoorspelbaarheid en onvermogen. En in een tijd als deze, waarin de wereld zo klein is geworden, denk bijvoorbeeld aan het internet of de mobiele telefoon, bieden deze studierichtingen juist een alternatief. Ze zullen de wereldse problemen zoals oorlog, ziektes en natuurrampen niet geheel kunnen oplossen - maar dat is ook niet hun doel. Zij stellen juist deze wereldse problemen aan de kaak door zich er het één en ander over af te vragen. Het maakt onze wereld weer groter, en dat is denk ik voor velen onder ons een verademing. Daarom was ik ook blij om te lezen dat de algemene universiteiten in Nederland samen een vuist hadden gemaakt tegen het rendementsdenken van de overheid. ${ }^{3}$

Toch maak ik mij nog steeds zorgen over de manier waarop het rendementsdenken zich als een Japanse duizendknoop door Nederland heeft verspreid. De huidige tendens van de overheid jegens alfastudies en de kunsten zorgt ervoor dat mensen steeds meer in cijfers zijn gaan denken en handelen. Ziekenhuizen en andere zorginstellingen moeten 'winst' maken, willen ze zich staande houden. Universiteiten moeten 'winst' maken om zich te kunnen meten met hun concurrenten. Het werkt een maatschappelijke afkeer tegen de alfastudies en kunsten in de hand omdat er geen economische meerwaarde achter schuilt. Bovendien valt het menselijke aspect van een samenleving weg als men elkaar gaat zien als nummers in plaats van mensen. Dit zorgt er langzamerhand voor dat elk greintje empathie uit mensen wordt gezogen, waardoor zij alleen nog maar geïnteresseerd zijn in hun eigen verhaal.

Dat denksystemen als deze niet snel zijn te veranderen is een misvatting aangezien er legio historische voorbeelden zijn te noemen waarbij denksystemen snel veranderden. Denk bijvoorbeeld aan de New Deal van F.D. Roosevelt of de drastisch hervormingen van de Labour partij in het Verenigd Koninkrijk na de Tweede Wereldoorlog. Dit waren ingrijpende veranderingen die onder de druk van sociale omstandigheden van de tijd tot stand kwamen. Om die reden houd ik de hoop dat de Nederlandse samenleving een toekomst tegemoet kan gaan waarin het rendementsdenken geen plaats meer heeft. Er zal geluisterd moeten worden naar de studenten en academici die zich in september opstelden tegen het rendementsdenken. 
Het zal geen makkelijke klus worden, maar de overheid zal moeten inzien dat vrijwel elke technologische vooruitgang alfastudies en kunst nodig heeft voor een completer beeld en maatschappelijke aanvaardbaarheid. Dit zijn niet alleen mijn woorden, maar ook die van Anton Pijpers, bestuursvoorzitter van de Universiteit Utrecht. ${ }^{4}$

Helaas kunnen de universiteiten het niet alleen voor elkaar krijgen om het rendementsdenken een halt toe te roepen. Gelukkig verscheen er dan ook afgelopen november een rapport van de Wereldgezondheidsorganisatie (WHO) over de rol van kunst in het verbeteren van de publieke gezondheid. Zo zouden kunstvormen als dans, muziek en theater een betekenisvolle rol spelen in het genezen en voorkomen van zowel fysieke als mentale ziektes. ${ }^{5}$ Dat ik hier - zonder wetenschappelijk onderzoek - zelf al achter was gekomen, heeft te maken met mijn eigen ervaringen rond de kunsten. Maar nu het wetenschappelijk onderbouwd is door het WHO kan ik dit argument gebruiken in mijn bittere strijd tegen mensen die zich dat niet kunnen beseffen.

Is het volledig uitbannen van het rendementsdenken dan mogelijk? Nee, en dat hoeft ook niet. Er zullen altijd mensen blijven, zoals enkele leden van mijn familie, die zich zullen blijven verzetten tegen mensen zoals ik. En dat is ook geen probleem, zolang zij de discussie maar aan de keukentafel blijven voeren en het niet omzetten in een landelijk beleid.

\section{Noten}

1. Eva Rensman, "De jaren tachtig van Onno Ruding 'Ik vond dat het verkeerd ging in Nederland," Historisch Nieuwsblad, augustus, 2001, https://www. historischnieuwsblad.nl/de-jaren-tachtig-van-onno-ruding/.

2. Mirjam Remi, "Universiteiten gaan tegen minister in en korten alfa-studies niet," NRC, 1 september, 2019.

3. Remi, "Universiteiten."

4. Remi, "Universiteiten."

5. Aya Sabi, "Met kunstsubsidies de Vlaamse identiteit zuiver houden, " NRC, 15 november, 2019. 